Russian Academy of Sciences

Far Eastern Branch

Botanical Garden-Institute

Institute of Biology and Soil Science

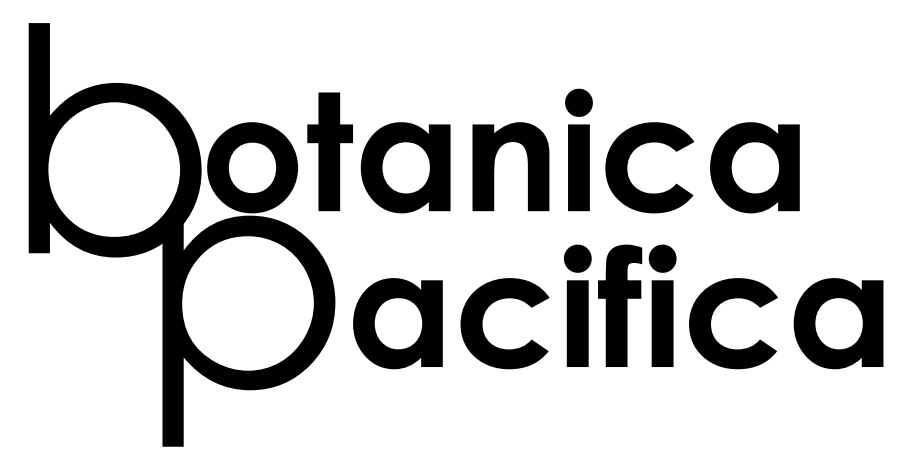

A JOURNAL OF PLANT SCIENCE
AND CONSERVATION

VOlUME 2, NO. 12013 
Botanica Pacifica

A JOURNAL OF PLANT SCIENCE AND CONSERVATION

VOLUME 2, NO. 12013
Botanica Pacifica (BP) publishes peer-reviewed, significant research of interest to a wide audience of plant versity, genetics, evolution, systematics), organization (molecular to ecosystem), and all plant groups and allied organisms (cyanobacteria, fungi, and lichens). Indexed by Russian Science Citation Index (http://elibrary.ru/title_about. asp?id $=34460$ ) scientists in all areas of plant biology (structure, function, development, di-
Botanica Pacifica (BP) пуболикует результаты исследований, прошедших независимую экспертизу и преАставАяющих значительный интерес широкому кругу ботаников во всех областях науки о растениях (структура, функции, развитие, разнообразие, генетика, эволюция и систематика), на всех уровнях организации живого (от молекулярного Ао экосистемного), по всем группам растений и родственным организмам (цианобактерии, грибы и кишайники). Индексируется Российским индексом научного цитирования (http://elibrary.ru/title_about. asp?id $=34460)$

\section{Chief editors:}

Pavel V. KRESTOV - Botanical Garden-Institute FEB RAS, Vladivostok, Russia

Peter G. GOROVOI - Pacific Institute of Bio-Organic Chemistry FEB RAS, Vladivostok, Russia

Vadim A. BAKALIN - Botanical Garden-Institute FEB RAS, Vladivostok, Russia

\section{Editorial board:}

Zumabeka AZBUKINA - Institute of Biology and Soil Science FEB RAS, Vladivostok, Russia Vyacheslav Yu. BARKALOV - Institute of Biology and Soil Science FEB RAS, Vladivostok, Russia Nadezhda I. BLOKHINA - Institute of Biology and Soil Science FEB RAS, Vladivostok, Russia Dmitrii E. KISLOV - Botanical Garden-Institute FEB RAS, Vladivostok, Russia

Andrei E. KOZHEVNIKOV - Institute of Biology and Soil Science FEB RAS, Vladivostok, Russia Yuri I. MANKO - Institute of Biology and Soil Science FEB RAS, Vladivostok, Russia Alexander M. OMELKO - Institute of Biology and Soil Science FEB RAS, Vladivostok, Russia Boris S. PETROPAVLOVSKII - Botanical Garden-Institute FEB RAS, Vladivostok, Russia Nina S. PROBATOVA - Institute of Biology and Soil Science FEB RAS, Vladivostok, Russia Larisa N. VASILYEVA - Institute of Biology and Soil Science FEB RAS, Vladivostok, Russia Yurii N. ZHURAVLEV - Institute of Biology and Soil Science FEB RAS, Vladivostok, Russia

\section{Editorial council:}

Konstantin S. BAIKOV - Institute of Soil Science and Agrochemistry SB RAS, Novosibirsk, Russia Elgene O. BOX - University of Georgia, Athens, USA

Victor V. CHEPINOGA - Irkutsk State University, Irkutsk, Russia

Klaus DIERSSEN - University of Kiel, Kiel, Germany

Nicolai B. ERMAKOV - Central Siberian Botanical Garden SB RAS, Novosibirsk, Russia

Andrew N. GILLISON - Center for Biodiversity Management, Yungaburra, Australia

Andrew M. GRELLER - Queens College, The City University of New York, New York, USA

Michael S. IGNATOV - Main Botanical Garden RAS, Moscow, Russia

Woo-Seok KONG - KyungHee University, Seoul, Republic of Korea

Nadezhda A. KONSTANTINOVA - Polar-Alpine Botanical Garden-Institute KSC RAS, Kirovsk, Russia Ilya B. KUCHEROV - Institute of Botany RAS, Saint-Petersburg, Russia

Victor Ya. KUZEVANOV - Botanical Garden of Irkutsk State University, Irkutsk, Russia

Yukito NAKAMURA - Tokyo University of Agriculture, Tokyo, Japan

Vladimir G. ONIPCHENKO - Moscow State University, Moscow, Russia

Dmitrii D. SOKOLOFF - Moscow State University, Moscow, Russia

Byung-Yun SUN - Chongbuk National University, Jeonju, Rep. Korea

Hideki TAKAHASHI - The Hokkaido University Museum, Hokkaido University, Sapporo, Japan Stephen S. TALBOT - US Fish and Wildlife Service, Anchorage, USA

Gennadii P. URBANAVICHUS - Institute of the Industrial Ecology Problems of the North KSC RAS, Apatity, Russia Pavel Y. ZHMYLEV - Moscow State University, Moscow, Russia

\section{Secretariat:}

Valentina A. KALINKINA - Botanical Garden-Institute FEB RAS, Vladivostok, Russia Eugenia V. BIBCHENKO - Botanical Garden-Institute FEB RAS, Vladivostok, Russia
(C) Botanica Pacifica 2012-2013. All rights reserved. No part of this publication may be reproduced, stored in a retrieval system or transmitted in any form or by any means without the written permission of the copyright holder. Requests for permission must be addressed to the editor.

C Botanica Pacifica 2012-2013. Bсе права защищены. Ни одна часть Аанного издания не может быть воспроизведена или передана в Аюбой форме и Аюббыми средствами (эмектронными, фотографическими или механическими), или представлена в поисковых системах без письменного разрешения держателя авторских прав, за которым следует обращаться к реАактору.

Издание зарегистрировано Федеральной службой по наАзору в сфере связи, информационных технологий и массовых коммуникаций Министерства связи и массовых коммуникаций Российской Федерации за № ПИ № ФС 77-52771

Journal Secretariat:

Botanica Pacifica

Botanical Garden-Institute FEB RAS

Makovskii Str. 142

Vladivostok 690024 RUSSIA

http://www.geobotanica.ru/bp

botanica.pacifica@icloud.com krestov@biosoil.ru v_bak@list.ru 


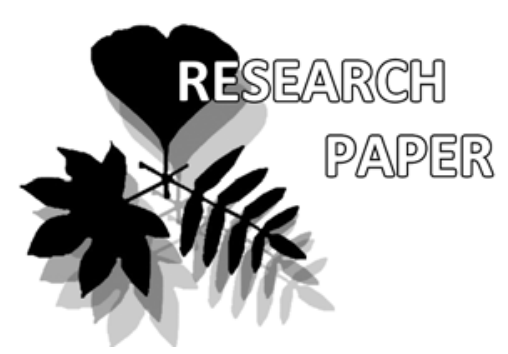

\title{
The Survey of Marchantiales from the Russian Far East I. The Review of Cleveaceae (Hepaticae)
}

\author{
Eugene A. BorovicheV ${ }^{1,2} \&$ Vadim A. BAKAliN $^{3,4}$
}

Eugene A. Borovichev ${ }^{1,2}$

borovichyok@mail.ru

Vadim A. Bakalin 3,4,*

v_bak@list.ru

${ }^{1}$ N. A. Avrorin's Polar-Alpine Botanical Garden-Institute KSC RAS

Apatity 184209 Russia

${ }^{2}$ Institute of the Industrial Ecology Problems of the North KSC RAS Apatity 184209 Russia

${ }^{3}$ Botanical Garden-Institute FEB RAS

Vladivostok 690024 Russia

${ }^{4}$ Institute of Biology \& Soil Science FEB RAS

Vladivostok 690022 Russia

* corresponding author

Manuscript received: 31.01.2013

Review completed: 21.04.2013

Accepted for publication: 28.04.2013

\begin{abstract}
A B S T R A C T
Cleveaceae (Marchantiales, Hepaticae) is reviewed for the Russian Far East. Within study area four species are recognized. Clevea byalina var. rufescens (S.W. Arnell) Konstant. is newly recorded for the Russian Far East and adjacent Republic of Sakha (Yakutiya). Many specimens were re-identified and the data on the intraregional distribution were strongly improved. Based on Far-Eastern material the identification keys to genera and species, their morphology and habitat descriptions, figures, as well as notes on distribution and lists of specimens examined are provided. Clevea nana (Shimizu \& S. Hatt.) Borovichev \& Bakalin comb. nov. is proposed

Keywords

Cleveaceae, Clevea, Sauteria, Pelptolepis, the Russian Far East, taxonomy, Hepaticae
\end{abstract}

\section{P E 3 Ю M E}

Боровичев Е.А., Бакалин В.А.

Обзор порядка Marchantiales с российского Аальнего Востока: I. Ревизия семейства Cleveaceae (Hepaticae)

Приведен обзор семейства Cleveaceae (Marchantiales, Hepaticae) на российском Аальнем Востоке. Всего в регионе известно 4 вила. ОАна разновиАность (Clevea byalina var. rufescens (S.W. Arnell) Konstant.) приводится впервые Аля российского Аальнего Востока и прилегающей части республики Саха (Якутия). В ходе проведенного исследования значительное количество изученных образцов было переопределено и, таким образом, распространение вилов существенно уточнено. Составлены кАючи Аля определения родов и виАов семейства, описаны распространение, морфология, экологические предпочтения всех таксонов, а также составлены оригинальные ил^юстрации. ПреАложена новая комбинация Clevea nana (Shimizu \& S. Hatt.) Borovichev \& Bakalin comb. nov.

ключевые слова

Cleveaceae, Clevea, Sauteria, Pelptolepis, российский Аальний Восток, таксономия, печеночники

\section{INTRODUCTION}

Cleveaceae is a family of Marchantiales Limpr. including thalloid liverworts. In the recent worldwide revision of the family by Rubasinghe (Rubasinghe 2011, Rubasinghe et al. 2011 a, 2011 b) four genera are recognized: Athalamia Falconer., Clevea Lindb., Sauteria (Nees) Nees and Peltolepis Lindb. This point of view differs from the most of previous works commonly regarding Clevea as a synonym of Athalamia (Schljakov 1982, Schuster 1992, Damscholt 2002). However, as it was shown by Rubasinghe et al. (2011b), the genus Athalamia is polyphyletic and consists of two groups - Athalamia s. str., including $A$. pinguis Falconer, $A$. bandelii (Herz.) S. Hatt., and Clevea with three species: $C$. byalina (Sommerf.) Lindb. (=A. byalina (Sommerf.) S. Hatt.), C. spatbysii (Lindenb.) Müll. Frib. (=A. spatbysii (Lindenb.) S. Hatt.), Clevea pusilla (Steph.) Rubasinghe \& D.G. Long (=A. pusilla (Steph.) Kashyap). Clevea nana (treated below as separate species) was included by cited authors to $C$. pusilla.

The genera of the Cleveaceae are widely distributed from Boreal and Temperate to Arctic regions throughout the
Northern Hemisphere, being much rarer in Southern Hemisphere and almost entirely absent from Tropics. According to the checklist of hepatics of Russia (Konstantinova et al. 2009), seven species of the family are known in Russia.

In the course of taxonomic revision of the Cleveaceae in the Russian Far East we found that the distribution of species is imperfectly known due to the misidentification of many specimens assigned to other species of the Cleveaceae and the Aytoniaceae. Thus, the distribution of Cleveaceae taxa in the Russian Far East needs to be clarified.

The present account is largely based on the critical revision of 165 specimens that are kept at the Botanical Garden-Institute FEB RAS, Vladivostok (VBGI, with incorporated collection from VLA), as well as on the materials from the Herbarium of the Polar-Alpine Botanical GardenInstitute (KPABG) and Komarov's Botanical Institute (LE). These herbaria comprise over $90 \%$ of all specimens available from the Russian Far East. As the result of the study we recognize four species of three genera of the Cleveaceae occurring in the Russian Far East. Below 
we provide the review on distribution, taxonomy and morphology of the Cleveaceae representatives of treated area. The distribution of each species in the Russian Far East was previously published by Bakalin (2010). However, data provided in this paper are partly out of date now, and many additional new localities were found, which are given here.

\section{Key to genera of the Cleveaceae of the Russian Far East}

1. Thallus light-green to whitish or yellowish-green, without secondary pigmentation even in exposed sites; upper surface rather fleshy to spongiose in lower part; ventral scales with oil-bodies; carpocephalum stalk with one rhizoid furrow

Sauteria [S. alpina].

- Thallus pale- or pure-green to reddish brown with reddish to purplish secondary pigmentation even in shaded sites (at least the bases of ventral scales are light pink or red-purplish); upper surface more or less flat; ventral scales without oil-bodies; carpocephalum stalk either without or with two rhizoid furrows

2.

2. Ventral scales not projecting beyond margin laterally; gynoecium terminal; androecial ostioles in sharply defined raised discs; carpocephalum stalk with two rhizoid furrows .

Peltolepis [P. quadrata].

- Ventral scales projecting beyond margin laterally (sometimes only slightly); gynoecium dorsal; androecial ostioles in distinct rows or loosely scattered; carpocephalum stalk without rhizoid furrow

Clevea.

SAUTERIA Nees, Naturg. Europ. Leberm. 4: 139. 1838 - Hampea Nees, Naturg. Europ. Leberm. 4: 139, 1838 (non Schlechtendal 1837, Bombacaceae), nom. inval. - Sauchia Kashyap in Journ. Bambay Nat. Hist. Soc. 24: 347. 1916.

\section{Type: Sauteria alpina (Nees) Nees}

Sauteria is the oligotypic genus with two species $-S$. alpi$n a$ (Nees) Nees and S. spongiosa (Kashyap) S. Hatt. (Rubasinghe 2011). Generally, species of Sauteria are arctomontane circumpolar, distributed mainly from tundra to northern taiga and in subalpine and alpine zones in the mountains of Eurasia and America (Singh \& Singh 2009, Borovichev et al. 2012) with disjunction in Africa (Perold 2003). The genus is represented in the Russian Far East by $S$. alpina only.

Sauteria alpina (Nees) Nees, Naturg. Europ. Leberm. 4: 143. 1838. - Lunularia alpina Nees in Nees \& Bisch., Flora (Regensburg) 13(2): 399. 1830. - Sauteria alpina (Nees) Nees var. angustifrons Kaal. in Jørgensen, Bergens Mus. Skr. 16: 27. 1934. - Sauchia japonica Shimizu \& S. Hatt., J. Hattori Bot. Lab. 9: 34. 1953. - Sauteria japonica (Shimizu \& S. Hatt.) S. Hatt. in Shimizu \& Hattori, J. Hattori Bot. Lab. 12: 62. 1954. - Sauteria alpina (Nees) Nees var. japonica Shimizu \& S. Hatt., J. Hattori Bot. Lab. 12: 64. 1954. - Sauteria yatsuensis S. Hatt. in Hattori \& Shimizu, J. Hattori Bot. Lab. 14: 99. 1955.

Description (Fig. 1): Thalli medium sized, 8-12 (-14) $\mathrm{mm}$ long, (2-)3-6 $\mathrm{mm}$ wide, forming more or less pure mats or often with an admixture to other bryophytes; simple or sparingly dichotomously branched, sporadically with ventral branches; segments prostrate, without any trace of secondary pigmentation; apex rounded or notched; upper surface rather fleshy to almost spongy or in basal parts almost flat, with air chambers convex and inflated, sometimes dorsal epidermis destroyed with age and surface becoming lacunose; color of upper surface light throughout to whitish or yellowish-green; thallus margins decolorans, slightly undulate. Dorsal epidermis delicate, hyaline, cells 30-40(45) $\mu \mathrm{m}$ wide, (45-)50-70(-80) $\mu \mathrm{m}$ long, with thin walls and small to conspicuous trigones; pores simple, stellate, surrounded by single ring of $5-7(8)$ cells with thickened radial walls or with thin radial walls, but then in 1-2 concentric rings of 5-8 cells in each, not stellate. Aerenchyma well developed, occupying $1 / 2-1 / 3$ of the thallus height in the middle, air chambers without photosynthetic filaments, isodiametric, elongated or narrow to canaliculate, 2-3(-4)-layered in the middle. Ventral tissue consisting of small, thinwalled cells, with solitary oil-cells, oil-bodies brownish to yellowish, (15-) $18 \times 28 \mu \mathrm{m}$ in diameter. Midrib relatively illdefined, thallus over midrib (450-)550-950 $\mu \mathrm{m}$ thick. Rhizoids smooth and pegged, densely covering ventral surface of midrib of thallus, hyaline. Ventral scales shiny, hyaline to silvery white, usually irregularly scattered on ventral surface, often more conspicuous and large near apex, not projecting laterally or sometimes clearly projecting near thallus apex, asymmetrically ovate to triangular, 350$700(-900) \mu \mathrm{m}$ long and (150-)200-600 $\mu \mathrm{m}$ wide; marginal one-celled slime papillae numerous; appendage one per ventral scale, acute to acuminate; body cells of ventral scales thin-walled, hyaline, large, 55-85(-95) $\mu \mathrm{m}$ long and $40-60 \mu \mathrm{m}$ wide more or less isodiametric, oil-bodies yellowish to pale gray, (0)2-5(-7) per ventral scale, oil-cells $15-23(-25) \mu \mathrm{m}$ in diameter. Sexual condition heteroicous. Androecia on both ventral and lateral branches or dorsally situated on leading thallus behind the female receptacle, ostioles from conical, without scales. Gynoecia arising in apical notch of leading thallus, later becoming lateral; stalk of receptacle hyaline or greenish, smooth, 7-15 $\mathrm{mm}$ long, with single rhizoidal furrow. Carpocephalum green to yellowish, cruciate to umbrella-shaped, disc convex, flat or concave medially, with (3-)4-6 relatively short lobes, each involucre with a single sporophyte. Capsule globose, brown to dull purplish, wall unistratose, cells of wall with annular to semiannular yellow-brown bands. Seta bulbous, short. Spores reddish brown, (45-)50-65 $\mu \mathrm{m}$, weakly tetrahedral, with hemispherical papillae. Elaters brownish, 2-3-spiral.

Ecology: Obligate calciphyte, growing along streams on fine-grained soil among rocks, on shady cliffs in narrow creeks of limestone rocks covered by soil, on fine ground between boulders in rocky fields, in snow bed communities, on solifluction spots in wet tundras, sometimes hidden between mosses.

Distribution: S. alpina has arcto-montane circumpolar distribution, occurring mostly from tundra to the north of taiga and in subalpine to alpine belts in the mountains of Eurasia and North America (Borovichev et al. 2012). It is known in the Russian Far East from Chukotsky Autonomous District, Kamchatsky Territory, Magadan and Sakhalinskaya Provinces.

Note 1: According to the checklist of hepatics of Russia (Konstantinova et al. 2009), two species of Sauteria were reported from Russia: S. alpina and S. japonica (Shimizu \& S. Hatt.) S. Hatt. As it was shown earlier (Borovichev et al. 2012) S. japonica regarded as synonymous with $S$. alpina. 


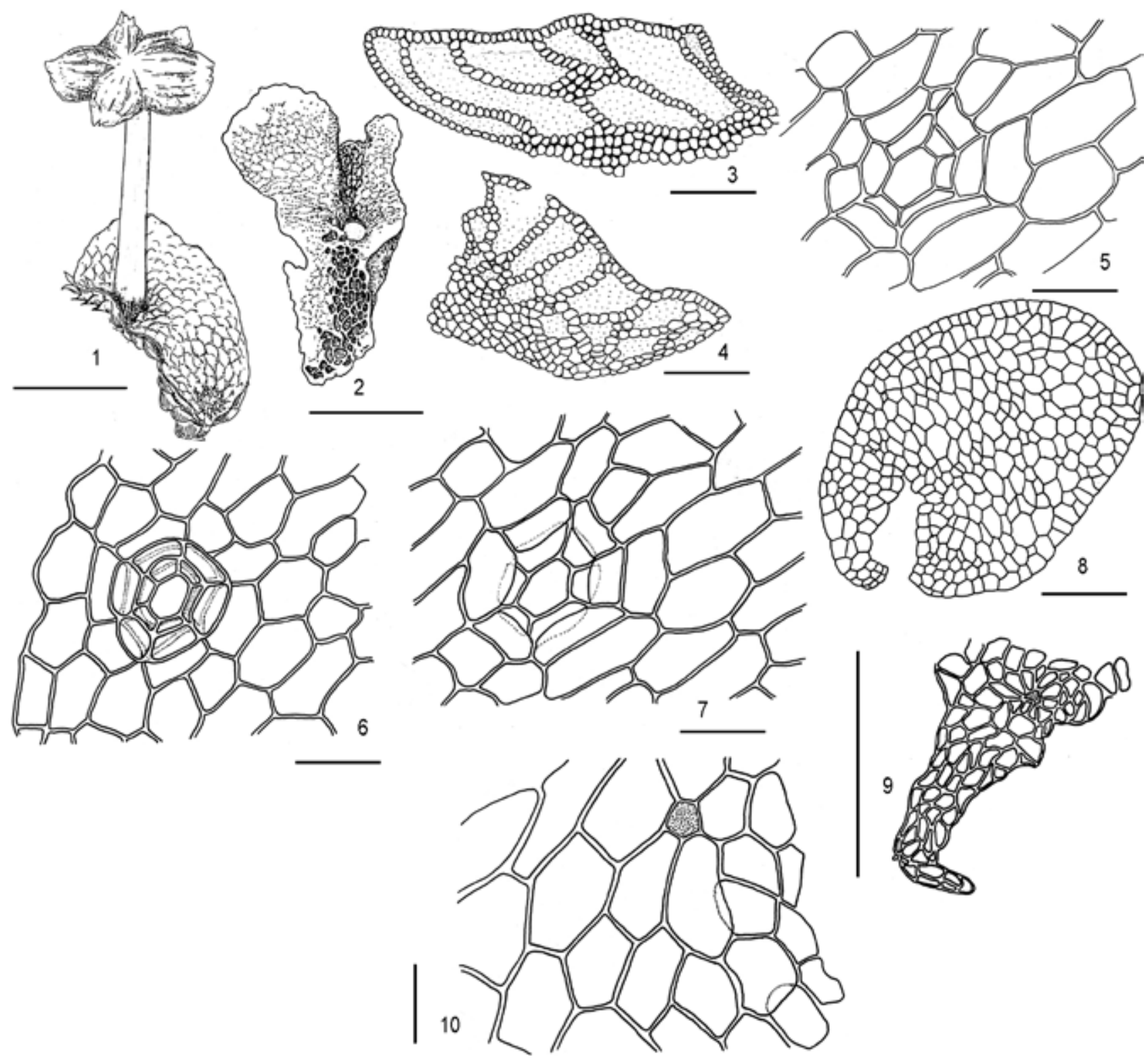

Figure 1 Sauteria alpina (Nees) Nees. 1,2 - thallus, dorsal view; 3, 4-transverse section of thallus; 5-7 - air pore of thallus dorsal epidermis; 8 - transverse section of receptacle stalk; 9 - ventral scales of thallus; 10 - cells of ventral scales. Scale bars: $4 \mathrm{~mm}$ - for 1, 2; $400 \mu \mathrm{m}$ - for 3,$4 ; 500 \mu \mathrm{m}-$ for $9 ; 200 \mu \mathrm{m}-$ for $8 ; 50 \mu \mathrm{m}-$ for $10 ; 40 \mu \mathrm{m}-$ for $5-7$

Note 2: Sauteria alpina is morphologically variable taxon, particularly in sexual condition. Autoicous plants predominate in the Russian Far East, but in some specimens (e.g. Mag-56-8-11 and Mag-56-9-11) both paroicous and autoicous plants are presented, although paroicous plants are rarer. Pseudo dioicous plants of Sauteria alpina reported by R. M. Schuster (1992) from Greenland and E. A. Borovichev et al. (2012) from Svalbard are also found in specimens from Magadan Province (e.g. Mag-41-15-11). The position of androecia on the greatly reduced stalked ventral innovations is regarded as supposedly specific for Sauteria spongiosa and "S. japonica" (Shimizu \& Hattori 1954, Hattori \& Shimizu 1955, Rubasinghe 2011), although slightly reduced male ventral branches are not rare in specimens from the Russian Far East and occur in tundra zone of Chukotka and Magadan Province as well as in Sakhalin Island.

New records from the Russian Far East: MAgadan Province: Khasynsky District, Ol'skoe Basalt Plateau, upper course of Maltan River, 60 $39^{\prime} 09^{\prime \prime} \mathrm{N}, 151^{\circ} 21^{\prime} 35^{\prime \prime E}, 1400 \mathrm{~m}$ alt., wet cliffs near the stream, 8.VIII.2011, V.A. Bakalin \#Mag-51-3-

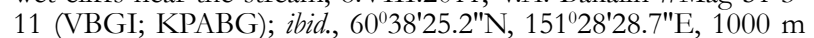
alt., narrow valley of the stream covered by the mosaic of open
Larix forest, Alnus thickets, grass tundra and gravelly barrens, peaty bank of the stream, 10.VI.2010, Bakalin \#Mag-9-3-10 (VBGI; KPABG); ibid., 6039'13"N, 151016'30"E, $970 \mathrm{~m}$ alt., small stream in Pinus pumila-Alnus fruticosa belt, fine-grained soil on the slope to the stream, 7.VIII.2011, Bakalin \#Mag-47-8-11 (VBGI); ibid., $60^{0} 38^{\prime} 47^{\prime \prime N}, 151^{\circ} 13^{\prime} 56^{\prime \prime E}, 1262 \mathrm{~m}$ alt., flat mountainous plateau covered by wet tundra, solifluction spots, fine-grained soil, 10. VIII.2011, Bakalin \#Mag-56-8-11 (VBGI; KPABG); ibid., $60^{\circ} 38^{\prime} 56^{\prime \prime} \mathrm{N}, 151^{0} 31^{\prime} 13^{\prime \prime} \mathrm{E}, 1100 \mathrm{~m}$ alt., moss tundra, wet slope to the stream, 10. VIII.2011, Bakalin \#Mag-57-11-11 (VBGI); Srednekanskiy District, Kolyma Upland, Tuonnakh Mts.,

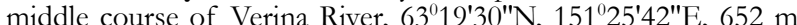
alt., on wet shady cliffs in narrow creek between limestone cliffs, 28.VII.2011, Bakalin \#Mag-41-15-11 (VBGI; KPABG).

Other specimens examined: RUSSIA, СнuкотsкY Autonomous District: Wrangel Isl., 25.VII.1985, O. M. Afonina (KPABG); 10.VIII.1985, Afonina (KPABG; LE); Nunligran 1.VII.1970, Afonina (KPABG); valley of Anadyr River, Southern Pekul'ney River, 10.VIII.1979, Afonina (LE), 24.VII.1980, Afonina (LE); Anadyr River Basin, upper course of the Yablon River, 7.VIII.1982, Afonina (KPABG); Cape of Krause, 1.IX.1975, Afo- 
nina (LE); Yanrakynnot Settlement vicinity, 9.VIII.1976, Afonina (LE); KaMChatsKY TerRITORY: Northern Koryakiya, 7.VIII.1984, Afonina (KPABG; LE); 8.VII.1988, E.Yu. Kuz'mina (KPABG); Northern Kamchatka, 11.VII.2003, Bakalin (KPABG, VBGI) Eastern Kamchatka, 24.VII.2003, Bakalin (KPABG); Bil'chonok Glacier, 21.VII.2003, Bakalin (KPABG, VBGI), 22.VII.2003, Bakalin (KPABG, VBGI), 24.VII.2003, Bakalin (KPABG, VBGI); upper course of the Kamenistava River, VIII.1981, A. Mikulin (KPABG, VBGI); Central Kamchatka, Bystrinskij Nature Reserve, West slope of Alnej Vlc., 13.IX.2004, Bakalin; 14.IX.2004, Bakalin; Sakhalinskaya Province: Sakhalin Island, Nabil'sky Range, upper course of Skalistaya River, 15.VIII.2006, Bakalin; 17.VIII.2006, Bakalin; 20.VIII.2006, Bakalin; Chamga Mt., 11.IX.2009, Bakalin (VBGI; KPABG); Vostochno-Sakhalinskiye Mts., 20.VI.2006, Bakalin (VBGI; KPABG).

PELTOLEPIS Lindb., Morgonbladet (Helsingfors) (106): 1, 1876; Bot. Notiser: 123, 1876.

Type: Peltolepis quadrata (Saut.) Müll. Frib.

Peltolepis is a monotypic genus including P. quadrata (Saut.) Müll. Frib.

Peltolepis quadrata (Saut.) Müll. Frib. Hedwigia 79: 74. 1940. - Sauteria quadrata Saut., Flora (Regensburg) 43: 351. 1860. - Sauteria alpina Ángstr. Bot. Notiser, 1839: 797 (p.p.; not of Nees, 1838). - Sauteria grandis Lindb., Medd. Soc. Fauna Fl. Fenn. 1: 113. 1876. - Peltolepis grandis (Lindb.) Lindb., Bot. Notiser, 1877: 74. - Peltolepis sibirica Lindb., Acta Soc. Fauna Fl. Fenn. 2(3): 4. 1882. - Peltolepis grandis (Lindb.) Lindb. var. sibirica (Lindb.) Lindb., Kongl. Svenska Vetenskapsad. Handl. 23(5): 12. 1889. - Peltolepis grandis (Lindb.) Lindb. var. angustifrons Lindb., Kongl. Svenska Vetenskapsad. Handl. 23(5): 13. 1889. - Peltolepis quadrata (Saut.) Müll.Frib. var. japonica Shimizu \& S.Hatt., J. Hattori. Bot. Lab. 12: 69, 1954. - Peltolepis japonica (Shimizu \& S. Hatt.) S. Hatt., in Hattori \& Shimizu, J. Hattori. Bot. Lab. 14: 103, 1955. - Peltolepis quadrata (Saut.) Müll. Frib. var. sibirica (Lindb.) Damsh., Ill. Fl. Nord. Liverw. Hornw.: 738. 2002.

Description (Fig. 2): Thalli small to medium sized, $2-7(-9) \mathrm{mm}$ wide, $5-12(-15) \mathrm{mm}$ long, forming more or less pure mats or often with an admixture to other bryophytes; 1-2-times dichotomously branched, rarely with ventral branches; segments prostrate, lingulate to linearlingulate; apex dilated to deep notched; upper surface firm and robust, smooth, reticulate with polygonal areas, one over each air-chambers, never lacunose; color of upper surface pale to dark green with purplish to rose tinge, frequent shining; thallus margins rather delicate, ascending, slightly undulate, with greenish or reddish to purplish secondary pigmentation. Dorsal epidermis delicate, cells mostly colorless, polygonal, (30-)35-55 $\mu \mathrm{m}$ long, (15-)20 $28(-35) \mu \mathrm{m}$ wide, thick-walled, trigones small or generally indistinct; oil-cells lacking or scattered; pores simple, not elevated to slightly elevated above epidermis, one per air-chambers; $18-25(-30) \mu \mathrm{m}$ in diameter, surrounded by single ring of 5-6(-7) cells with thickened radial walls, such as they look stellate, or rarely not thickened. Aerenchyma well-developed, occupying $1 / 3-1 / 4$ of the thallus height in the middle and ca $1 / 2$ in the wings, air chambers without photosynthetic filaments, isodiametric to elongated, 2-3-layered in the middle, 1-layered in the wings. Ventral tissue without oil-cells, $1 / 2-2 / 3$ the thallus thickness in the middle. Lower surface greenish to rose, covered by ventral scales. Midrib relatively ill-defined to rounded keel, thallus over midrib 650-950 $\mu \mathrm{m}$ thick in cross-section. Rhizoids smooth and pegged, hyaline to rose, forming dense cluster along midrib region. Ventral scales in irregular rows on the ventral surface, hyaline to rose or reddish, never blackish purple; not projected behind thallus or slightly projecting behind margin thallus, asymmetrically ovate to triangular, $350-950 \mu \mathrm{m}$ long and 250-450(-600) mm wide; marginal one-celled slime papillae 2-3 per ventral scale; appendage one per ventral scale, ill-defined to acute; body cells of ventral scales thick-walled, hyaline to rose, more or less polygonal, 40-55(-71) $\mu \mathrm{m}$ long and (26-)30-35 $\mu \mathrm{m}$ wide, oil-cells absent. Vegetative propagation is lacking. Sexual condition heteroicous. Anteridia forming in dorsal, compact well-defined disc, usually situated on leading thallus behind or before the female receptacle or on separate terminal branch; disc elliptical to circular, somewhat elevated surrounded by 4-6 purplish, ovate to elongate antheridial scales; apex antheridial scales with numerous marginal one-celled slime papillae. Gynoecia terminal, arising in a deep apical notch of leading thallus, later becoming lateral; stalk of receptacle greenish to purplish generally in the base, smooth, 7-10 mm long, with two rhizoidal furrows, naked. Archegonial scales at base of receptacle stalk absent, at apex numerous, lanceolate to almost linear, hyaline to purplish, with many slime papillae; carpocephalum green with purple tinge, umbrella-shaped, disc convex, flat or concave medially, ovate to obovate in outline, with 4-6(-7) relatively pointing downwards or horizontal, with small air-chambers, simple pores present or absent; each involucre with single sporophyte. Capsule globose, deep brown dehiscing by 4-6 irregular valves, wall unistratose, cells of wall with weakly pigmented annular to semiannular brownish bands. Seta bulbous, short. Spores reddish brown to brown, (40-)50-60 $\mu \mathrm{m}$, spherical, densely covered by hemispherical papillae, lack distinct wing margins. Elaters brownish, (2-)3-spiral, (60-)90-170 $\mu \mathrm{m}$ long, 8-10 $\mu \mathrm{m}$ wide.

Ecology: This species is an obligate calciphyte, commonly growing on calcium-rich substrata (both humic and fine-grained mineral soil). At lower elevations it occurs chiefly on shady, moist steep slopes or cliff clefs, whereas in tundra zone and in corresponding mountain belt it occurs in open wet places and in snowbed habitats.

Distribution: Peltolepis quadrata has arcto-montane circumpolar distribution, and occurs from tundra to northern taiga and subalpine and alpine belts in the mountains of Eurasia and North America (Schuster 1992, Damsholt 2002, Rubasinghe 2011). In the Russian Far East it is currently known from Chukotsky Autonomous District, Kamchatsky, Primorsky and Khabarovsk Territories, Magadan and Sakhalin Provinces.

Note: According to the checklist of hepatics of Russia (Konstantinova et al. 2009), both of worldwide recognized species of Peltolepis were reported for Russia: P. quadrata and $P$. japonica (Shimizu \& S. Hatt.) S. Hatt. Afterwards, it was shown by S. Rubasinghe (2011) that P. japonica is the later synonym of $P$. quadrata. We agree with this conclusion. According to Shimizu \& Hattori (1954) P. japonica differs from P. quadrata by (1) smaller size; (2) not so firm texture; (3) ovate ventral scales and (4) 

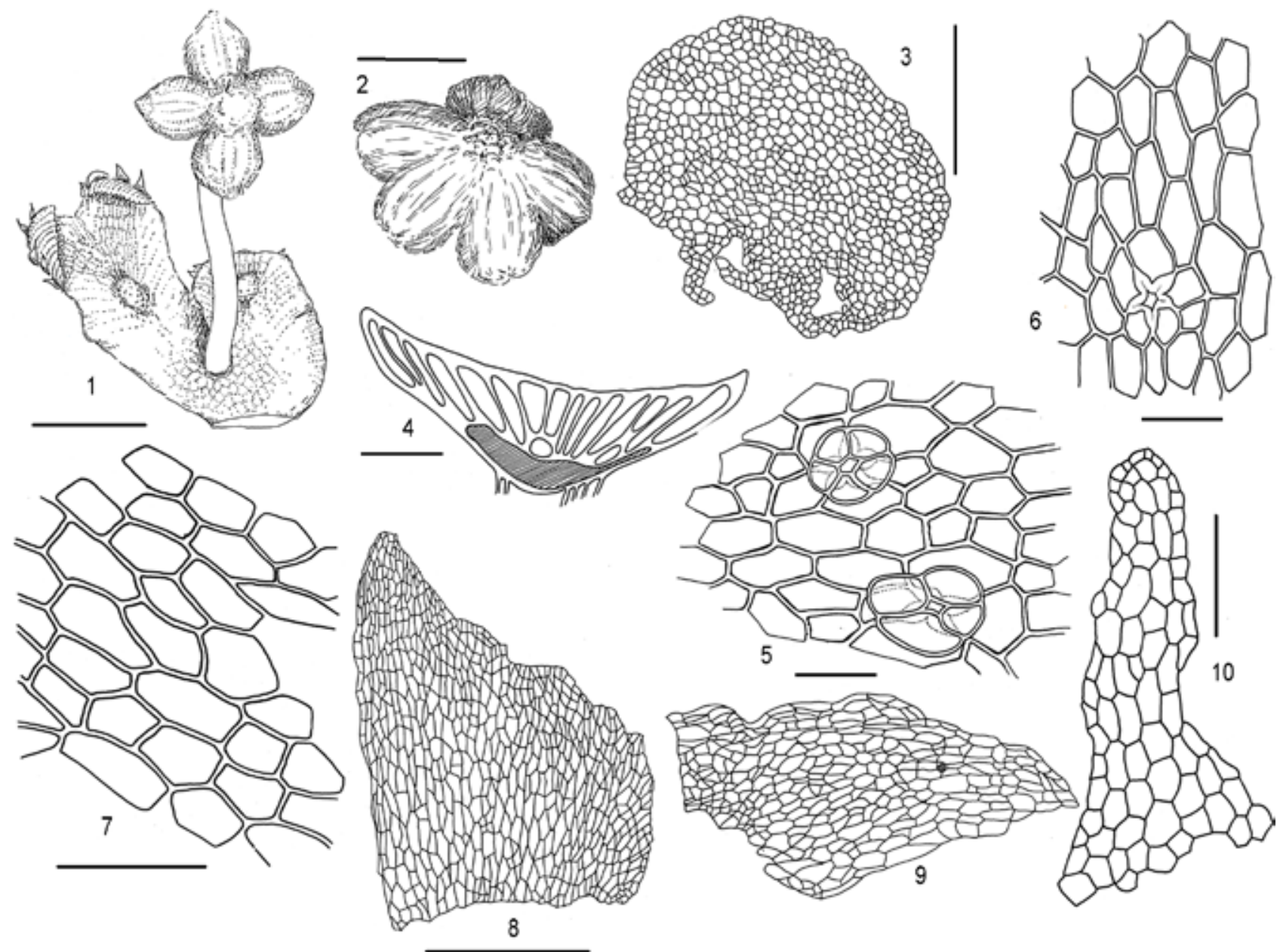

Figure 2 Peltolepis quadrata (Saut.) Müll. Frib. 1 - thallus, dorsal view; 2 - carpocephalum, dorsal view; 3 - transverse section of receptacle stalk; 4 - transverse section of thallus; 5, 6 - air pores of thallus dorsal epidermis; 7 - dorsal epidermis of thallus; 8-10 - ventral scales of thallus. Scale bars: $4 \mathrm{~mm}$ - for 1; $2 \mathrm{~mm}$ - for $1.5 \mathrm{~mm}$ for 2; $500 \mu \mathrm{m}$ - for 4; $350 \mu \mathrm{m}$ - for 3; $250 \mu \mathrm{m}-$ for 8,$10 ; 200 \mu \mathrm{m}-$ for 9 ; $20 \mu \mathrm{m}$ - for $5-6 ; 40 \mu \mathrm{m}$ for 7

carpocaephala without pores, disk is flattish above and never convex. During this study we found that shape of ventral scales, the degree of reduction of receptacle tissue, and the presence/ absence of pores in receptacular tissue are highly variable features even within one specimen. Thus, the variability of listed features supports the treatment of Peltolepis as a monotypic genus. As the result, all records of $P$. japonica from the Primorsky Territory should be referred to $P$. quadrata.

New records from the Russian Far East: Magadan Province: Khasynsky District, Ol'skoe Basalt Plateau, upper course of Maltan River, 60 $39^{\prime} 09^{\prime \prime N}, 151^{\circ} 21^{\prime} 35^{\prime \prime} \mathrm{E}, 1400 \mathrm{~m}$ alt., wet slope, 8.VIII.2011, Bakalin \#\#Mag-51-57-11 (VBGI; KPABG); ibid., south-facing slope of the Mt. $1350 \mathrm{~m}$ alt., 6038'37.7"N, $151^{\circ} 26^{\prime} 21.5^{\prime \prime E}, 1150 \mathrm{~m}$ alt., crevices in the gravelly barren field, 11.VI.2010, Bakalin \#\#Mag-11-37-10a (VBGI; KPABG); КнABAROvsK TERRITORY: Nanajsky District, Tardoki-Yani Range, $48^{0} 53.285 \mathrm{~N}, 138^{\circ} 02.905 \mathrm{E}, 1920 \mathrm{~m}$ alt., cliff ledge, 29.VIII.2012, V. Y Barkalov \#\#10, 16 (VBGI).

Other specimens examined: RUSSIA, СникотsкY Autonomous District: Kresty Bay, Egvekinot Settlement vicinity, 19.VIII.1977, Afonina (LE); Petlyanen River, 18.VIII.1972, V. V. Razzhivin (KPABG); Cape of Krause, 29.VIII.1975, Afonina (LE, as Athalamia hyalina); Tanyurer River Basin 14.VII.1979, Afonina (KPABG); Inchoun Settlement, 8.VIII.1975, Afonina (KPABG); Kamchatsky Territory: Eastern Kamchatka, Pinachevskaya River Valley, 11.VIII.2001, Bakalin (KPABG, VBGI), Bil'chonok Glacier, 24.VII.2003, Bakalin (KPABG, VBGI), 22.VII.2003, Bakalin (KPABG, as Sauteria alpina); upper course of the Kamenistaya River, VIII.1981, Mikulin (KPABG,
VBGI); Northern Kamchatka, upper course of the Palana River, 11.VII.2003, Bakalin (KPABG, VBGI, as Athalamia hyalina); Bering Island, 10.VIII.2002, Bakalin (KPABG), 18.VIII.2002, Bakalin (KPABG, VBGI, as Athalamia byalina); Sakhalinskaya Province: Sakhalin Island, Nabil'sky Range, in head of Khrebtovy Stream from Chamga Mt., 11.IX.2009, Bakalin (VBGI; KPABG as Sauteria alpina); Primorsky Territory, Olginskij District, Margaritovo Settlement vicinity, 24.VIII.1980, S. K. Gambaryan (VBGI, as P. japonica); JAPAN: Nagano County, Akadoike Peak of the Yatsu volkano, 21.VIII.1953, D. Shimizu (Isotype VBGI, isotype of Peltolepis quadrata (Saut.) Müll.Frib. var. japonica Shimizu \& S. Hatt. from Hepaticae Japonicae Exsiccatae \#253); Isotype \#52826 NICH).

CLEVEA Lindb., Notiser Sällsk. Fauna Fl. Fenn. Förhandl. 9: 28. 1868. - Spathysia Nees Naturg. Europ. Leberm. 4: 178, 1838. nom. inval. (Art. 34.1 (b)). - Spathysia Nees ex Trevis., Memorie Real. Istit. Lombardo Sci. Mat. Nat. ser. 3, 4: 439. 1877. - Gollaniella Steph., Hedwigia 44: 74, 1905. - Athalamia Falc., Ann. Mag. Nat. Hist. ser. 2, 1: 375, 1848; Trans. Linn. Soc. London 20: 397.1851 (p.p. exluding type).

Type: Clevea byalina (Sommerf.) Lindb.

Thalli small to medium sized, (3-)5-8(-15) mm long and $1.5-6 \mathrm{~mm}$ wide, pale- or pure green to brownish, often with reddish tinge, non aromatic in fresh condition; simple or dichotomously terminally branched, occasionally 
with ventral innovations; margin slightly to strongly undulate or scalloped, greenish, purplish to whitish brown. Upper surface rigid to delicate, polygonally reticulated (at least in younger parts), each polygon corresponds to each air-chamber inside of thallus. Epidermal cells in one layer, thick- or thin-walled, pores simple, slightly elevated above epidermis, surrounded by a single row composed by $4-5(-7)$ cells, with radial walls strongly unequally thickened ("stellate") to not thickened; without oil-cells. Ventral tissue developed in middle part of thallus and almost absent in the wings; without oil cells. Aerenchima well developed, (1)2-3(-4) layered, air chambers in the thallus cross section middle rounded or polygonal to narrower, without photosynthetic filaments and oil-cells. Midrib not strongly protruding on ventral surface, gradually narrowed to wings. Rhizoids dimorphic: smooth or pegged, hyaline to milky whitish, forming dense cluster or scattered along midrib region. Ventral scales hyaline to purplish or blackish purple, lanceolate or ovate, projecting beyond margin both apically and laterally (sometimes only slightly), occasionally forming a conspicuous dense brush at apical part of thallus; oilcells absent; marginal one-celled slime-papillae present or lacking; appendage by one per ventral scale, long-acute to acuminate. Vegetative propagation lacking. Sexual condition dioicous, autoicous or paroicous. Androecia on separate male plant or terminal branch or on the same plant behind base of archegoniophore; ostioles conspicuous, greenish to purplish, with or without androecial scales. Archegoniophores dorsal, 1-3 on each plant, along midline; receptacle stalk light hyaline, green to purple tinged, smooth, without rhizoid furrow, apical stalk scales present, hyaline to purplish-tinged, linear or linear-lanceolate, with cells thin-walled, without oil cells; carpocephalum smooth or warted, umbrella- or cup-shaped, 2.5-4 $\mathrm{mm}$ in diameter, with a few or lacking air chambers and simple pores, deeply 1-4(-6) lobed, lobes turned downwards, horizontally or upwards, each involucre bearing one sporophyte; pseudoperianth lacking. Capsule dark brown, globose, with unistratose wall; wall cells with annular and semi-annular bands. Seta short. Spores coarsely papillose reddish brown. Vegetative propagation lacking.

Clevea has a nearly worldwide distribution, although still are not recorded from Australia and New Zealand. Their distribution is connected with mountainous ranges (Rubasinghe 2011). The genus includes four species, two of them are known in the Russian Far East and one (C. pusilla) is recorded from adjacent areas in China and Japan and may be found in our area.

\section{Key to species of Clevea in the Russian Far East and adjacent area}

1. Plants dioicous; pores with \pm thick radial walls such as looks stellate; ventral scales hyaline to purplish, never blackish purple.

C. hyalina.

- Plants monoicous; pores with thin radial walls, not stellate; ventral scales purple to blackish purple or sometimes hyaline ... 2 .

2. Plants autoicous, with antheridia on separate terminal branch of the same thallus; thallus \pm thin, ca. 150-200
$(-350) \mu \mathrm{m}$ thick at the middle; thallus margins \pm prostrate in wet conditions; ventral scales dichromatic (with markedly defined colorless appendage and purple colored body); sciophytic mesophyte C. nana.

- Plants paroicous, with antheridia on main thallus behind the female receptacle; thallus \pm thick and spongiose, ca. $300-550(-700) \mu \mathrm{m}$ thickness at the middle; thallus margins slightly incurved in wet conditions; ventral scales monochromic (both body and appendage often pink to purplish colored); heliophytic xerophyte [C. pusilla].

Clevea hyalina (Sommerf.) Lindb. Not. Sällsk. pro Fauna et Flora Fennica 9:291. 1868. - Marchantia cruciata Sommerf., Suppl. Florae Lapponicae 79, 1826. nom. illeg. non L. - Marchantia byalina Sommerf., Magazin Naturvidensk. (Christiana) II. Ser., I, fasc. 2: 234. 1833. - Sauteria byalina (Sommerf.) Lindb., Öfvers. Förh. Kongl. Svenska Vetensk.Akad. 23: 561, 1867. - Athalamia byalina (Sommerf.) S. Hatt., J. Hattori Bot. Lab. 12: 54, 1954. - Sauteria suecica Lindb., in Gottsche \& Rabenhorst, Hep. Eur. no. 347, 1866. - Clevea byalina (Sommerf.) Lindb. var. suecica (Lindb.) Lindb., Bot. Not. 7: 78. 1877. - Clevea suecica (Lindb.) Lindb., Musci Scand. 9: 1. 1879. - Clevea byalina (Sommerf.) Lindb. var. kernii Müll.Frib. ex Kern, Jahresber. Schles. Ges. 86: 14. 1908. - Clevea trabutiana Steph. Sp. Hepat. 6: 5, 1917. - Athalamia trabutiana (Steph.) S. Hatt., J. Hattori Bot. Lab. 12: 54, 1954.

Description (Fig. 4): Thalli medium sized, 6-12 $\mathrm{mm}$ long, 3-5(-7) mm wide; forming compact patches or rarely growing as single plants over or among mosses; dichotomously branched, ventral branches present; segments widely obovate to widely lingulate and lingulate; apex rounded to slightly notched; upper surface distinctly reticulate in younger parts, obscurely reticulate with age; color of upper surface pale- or pure green to reddish-brown, in older parts often somewhat nitid; thallus margins slightlyto strongly incurved when dry and almost plane when wet, thin, undulate to scalloped, purplish to brownish or whitish brown. Dorsal epidermis cells thin- to moderately thickwalled, 40-60×25-40 $\mu \mathrm{m}$; pore simple, $13-18(-21) \mu \mathrm{m}$ in diameter, surrounded by $5-7$ cells, radial walls often strongly thickened such as look stellate. Thallus cross-sections 土thin, 400-600 $\mu \mathrm{m}$ at midrib. Ventral tissue developed in middle part of thallus and almost absent in the wings, occupying $1 / 2-1 / 3$ the thallus thickness near the apex, at the younger parts, but $1 / 4-1 / 5$ in the middle of older parts. Aerenchima well developed, occupying $1 / 2-2 / 3$ the thallus thickness; 2-3(-4)-layered in the thallus middle; airchambers polygonal to narrower, without photosynthetic filaments. Lower surface pale brown to greenish, hidden in ventral scales; midrib not strongly protruding on ventral surface, in middle part of thallus often rounded, gradually narrowing into wings. Rhizoids hyaline to milky whitish, forming dense cluster along midrib region. Ventral scales in several irregular longitudinal rows, hyaline to rose or pale purplish, never blackish purple; triangular to lanceolate, \pm projecting behind thallus margin both apically and laterally (often only slightly), sometimes forming a conspicuous dense brush at apical part of thallus, (250-)400-800(-1050) $\mu \mathrm{m}$ long and (160-)250-680 $\mu \mathrm{m}$ wide; body cells of ventral scales thin-walled, hyaline to rose, large, (45-)60-86 
$\mu \mathrm{m}$ long and (30-)45-60 $\mu \mathrm{m}$ wide; appendage by one per ventral scale, narrowly long-acute to acuminate; oil-cells absent; marginal one-celled slime-papillae $0-4$ per ventral scale. Sexual condition dioicous. Male and female plants intermixed, male plants smaller. Androecia dorsal, in antheridial ostioles, scattered along median line of the thallus, ostioles greenish to purplish, conspicuous, androecial scales lacking or one for each ostiole to numerous, rose to purplish, 200-350 $\mu \mathrm{m}$ long, with 1-4(-6) hyaline to rose appendages. Gynoecia dorsal, 1-3 along the midline, when unfertilized surrounded by a cluster either hyaline or purplish lanceolate scales; receptacle stalk cylindrical, hyaline to (generally at base) purplish, smooth, 5-9 mm long; apical stalk scales present, situated below carpocephalum; carpocephalum yellowish- to brownish green, umbrellashaped, deeply 2-5-lobed, rarely horizontal, each involucre containing one sporophyte. Capsule globose, dehiscing by 3-5 irregular valves, wall unistratose, cells spindle-shaped, 40-60 mm long, 22-30 mm wide, with annular and semi-annular bands. Seta bulbous short up to $0.5-0.6 \mathrm{~mm}$. Spores reddish brown to brown, $40-60 \mu \mathrm{m}$ in diameter, surface densely covered by hemispherical sacs, obtuse. Elaters brown, 150-225 $\mu \mathrm{m}$ long, 8-10(-11) $\mu \mathrm{m}$ wide, 2-4 spiral.

Clevea byalina in the Russian Far East falls into two varieties: C. byalina var. byalina and Clevea byalina var. rufescens (S. W. Arnell) Konstant.

Clevea hyalina var. hyalina is characterized by: 1) paleor pure green with purplish tinged upper surface of thallus; 2) purple to reddish tinged thallus margins; 3 ) \pm thin-walled cells of dorsal epidermis; 4) absence of androecial scales or rare presence of androecial scales by one for each ostiole.

It is more or less rare taxon being known in the Russian Far East in Chukotsky Autonomous District and Kamchatsky Territory only.

Specimens examined: RUSSIA, ZABAIKAL'SKY TERRITORY, Chita City Area 26.IX.1909, P. Mihno (KPABG); Снuкотsкy Autonomous District, Anadyr River Basin, Enmynvaam River 3.VII.1980, Afonina (LE); Yanrakynnot Settlement vicinity 23.VI.1976, Afonina (LE, KPABG, as Mannia); Arakachechen 9.VIII.1962, V. Gavrilyuk (KPABG as Peltolepis quadrata); Cape of Krause, 30.VIII.1975, Afonina (LE); Kamchatsky TerritoRY: Bering Island, 10.VIII.2002, Bakalin (KPABG as Peltolepis quadrata).

Clevea hyalina var. rufescens (S. W. Arnell) Konstant. Polish Botanical Journal 57(1):185. 2012. - Clevea byalina $\mathrm{f}$. rufescens S. W. Arnell in S. W. Arnell \& O. Mårtens. Ark. Bot. Ser. 4(6):123. 1959. - Athalamia byalina f. rufescens (S. W. Arnell) Damsh., Ill. Fl. Nord. Liverw. Hornw.: 745. 2002.

C. byalina f. rufescens S. W. Arnell was elevated to a variety - Clevea hyalina var. rufescens by Konstantinova (Konstantinova \& Savchenko 2012) basing on the studies of the material from Svalbard. It is characterized by: 1) red-brown colored upper surface of thallus; 2) brownish to whitish brown thallus margins; 3) moderately thick-walled cells in dorsal epidermis; 4) numerous purplish colored antheridial scales in male plants. The variety has never been reported for the Russian Far East and East Siberia. In the course of the present research we were able to identify it from Chukotsky Autonomous District, Magadan Province as well as westward adjacent Republic of Sakha (Yakutiya).
Both $C$. byalina var. rufescens and C. byalina var. byalina are obligate calciphytes. They mostly grow on calcareous soil in small crevices or caves on steep slopes, cliffs of limestone or schist, detritus in small crevices in calcareous rocks, in snow bed communities, solifluction spots in wet tundras, where often hidden between mosses.

New records: RUSSIA, KRASNOYARSK Territory, Mariya Pronchischeva Bay, 10.VIII.1972, N. V. Matveeva (KPABG); Chuкotsky Autonomous District, Wrangel Island, Somnitel'naya Bay, $\sim 70^{\circ} 55^{\prime} \mathrm{N}, 179^{\circ} 28^{\prime} \mathrm{E}$, snowbed communities on southern slope, on fine-grained soil, 23.VII.1985, Afonina (KPABG, VBGI), 10.VIII.1985, Afonina (LE); ibid., Papaver-Pedicularis-communities on lower sea terrace, on rock cracks, 21.VII.1985, Afonina (KPABG, VBGI); Pikul'ney Range, Tanyurer River Basin, Bezymyannoe Lake vicinity, $64^{\circ} 51^{\prime} 01^{\prime \prime N}$, $174^{\circ} 28^{\prime} 33^{\prime \prime} \mathrm{E}$, solifluction spot, on fine-grained soil, 14.VII.1979, Afonina (KPABG, VBGI), ibid., mountain fruticulose-grassesmoss tundra, on fine-grained soil among mosses, 18.VII.1979, Afonina (LE, KPABG); Anadyr River Basin, upper course of the Enmynvaam, $\sim 66^{\circ} 12^{\prime} 27^{\prime \prime} \mathrm{N}, 173^{\circ} 31^{\prime} 51^{\prime \prime E}$, cliffs rocks on slope, on fine-grained soil, 3.VII.1980, Afonina (KPABG); MAGADAN Province, Kolyma Upland, Tuonnakh Range, upper course of the Verina River, $63^{\circ} 16^{\prime} 41^{\prime \prime N}, 151^{\circ} 03^{\prime} 44^{\prime \prime} \mathrm{E}, 1340 \mathrm{~m}$ alt., tundra belt, stony fields, fine-grained soil near stream, 23.VII.2011, V.A. Bakalin \#Mag-26-3-11 (VBGI, KPABG). New records from the area adjacent to the Russian Far East: Republic of SAKHA (YAKUTIA), the middle part of the course Indigirka River, In'yaly River, $\sim 65^{\circ} 22^{\prime} 46^{\prime \prime} \mathrm{N}, 141^{\circ} 56^{\prime} 35^{\prime \prime} \mathrm{E}$, stony slope, on fine-grained soil, 20.VI.1976, Afonina (LE, KPABG).

Clevea nana (Shimizu \& S. Hatt.) Borovichev \& Bakalin

We propose Clevea pusilla (Stephani) Rubasinghe \& Long and Athalamia nana although being related, nevertheless are not conspecific. Main differences "Athalamia nana" from Clevea pusilla are given in the key. A new combination is needed to be proposed - Clevea nana (Shimizu \& S. Hatt.) Borovichev \& Bakalin comb. nov. - Basionym: Gollaniella nana Shimizu \& S. Hatt., J. Hattori Bot. Lab. 9: 34. 1953. - Athalamia nana (Shimizu \& S. Hatt.) S. Hatt. in Shimizu \& Hattori, J. Hattori Bot. Lab. 12: 54. 1954. - Athalamia glauco-virens Shimizu \& S. Hatt., J. Hattori Bot. Lab. 12: 56. 1954. - Athalamia glauco-virens Shimizu \& S. Hatt. f. subsessilis Shimizu \& S. Hatt., J. Hattori Bot. Lab. 12: 58. 1954.

Description (Fig. 4): Thalli small to medium sized, (3-)5-8(10) $\mathrm{mm}$ long, 1.5-3(-4) $\mathrm{mm}$ wide, in older thalli to $12 \mathrm{~mm}$ long and 4-6 $\mathrm{mm}$ wide; growing as single plants or among mosses or forming compact patches; simple or 1-3 dichotomously branched, ventral branches rare; segments wider ovate to \pm lingulate; apex slightly- to deeply notched; upper surface with small polygonal areas, air-chambers partitions prominent, but pores \pm visible in wet conditions only; color of upper surface pale- to dark green; margins incurved, clearly purplish along margin and thallus apex in dry conditions, \pm flattened in wet conditions, with purplish tinge, sometimes greenish along margin, undulate to scalloped. Upper epidermal cells delicate, thin-walled, slightly yellowish or rose to hyaline, isodiametric, $28-35 \times 25-30$ (35) $\mu \mathrm{m}$, with distinct trigones, oil cells in epidermis lacking; pores simple, 8.0-18.0(-20) $\mu \mathrm{m}$ in diameter, surrounded by a single row of $4-5(-7)$ cells, with radial walls slightly thickened (never stellate) to not thickened. Thallus cross-sections \pm thin, $\sim 150-200(-350) \mu \mathrm{m}$ at midrib. Ventral tissue occupying 1/3-1/2 near the apex and at the younger parts, but almost not defined in middle of older parts, confined only in middle part of cross-section 


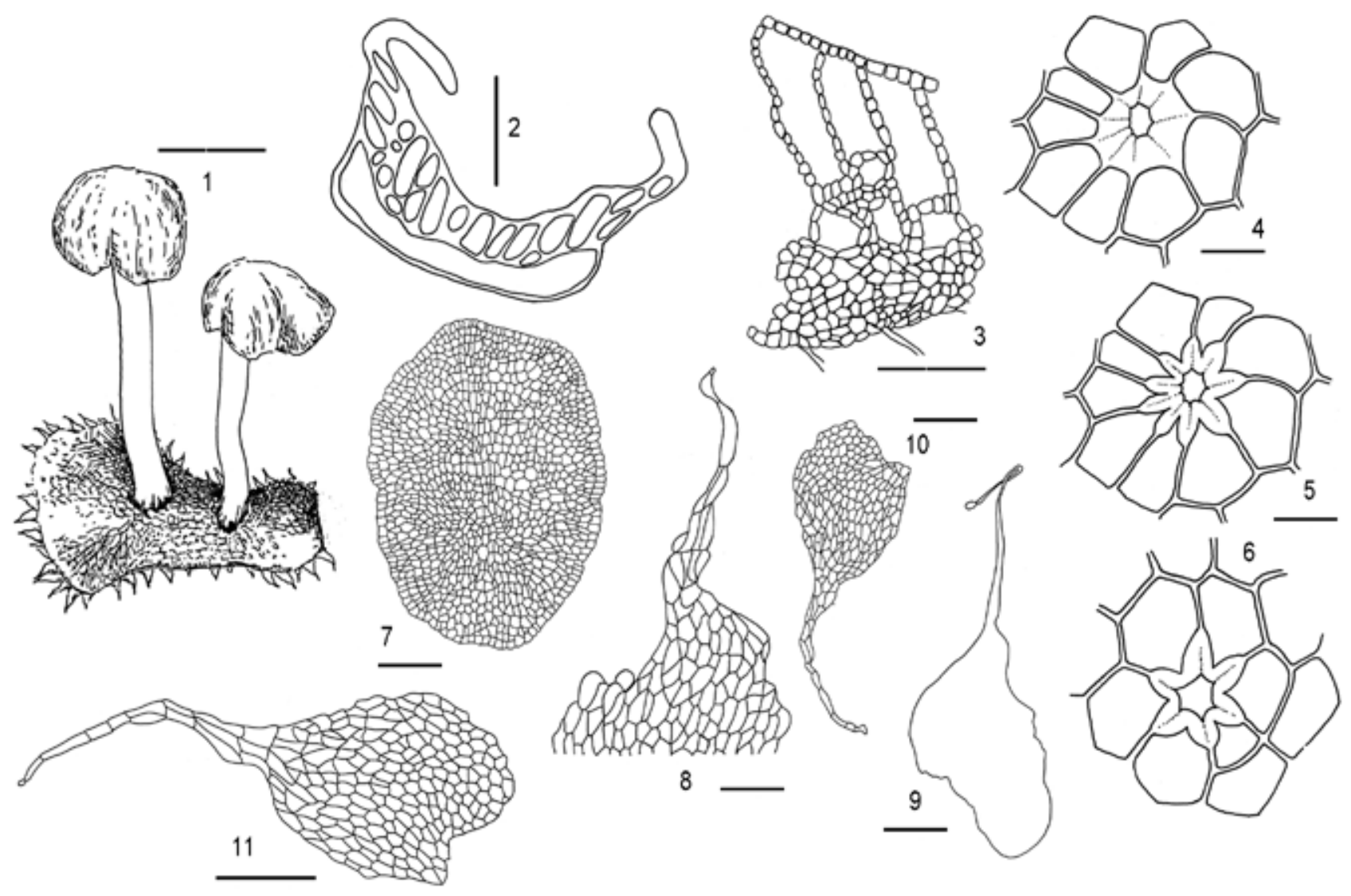

Figure 3 Clevea hyalina (Sommerf.) Lindb. 1 - female thallus, dorsal view; 2, 3-transverse section of thallus; 4-6 - air pores of thallus dorsal epidermis; 7 - transverse section of receptacle stalk; 8-11 - ventral scales of thallus. Scale bars: $3 \mathrm{~mm}-$ for $1 ; 400 \mu \mathrm{m}-$ for $2 ; 250 \mu \mathrm{m}-$ for $3 ; 200 \mu \mathrm{m}$ - for $11 ; 150 \mu \mathrm{m}$ - for 7, 9-10; $100 \mu \mathrm{m}$ - for $8 ; 40 \mu \mathrm{m}$ for $4.3 ; 250 \mu \mathrm{m}-$ for 8,$10 ; 200 \mu \mathrm{m}-$ for $9 ; 20 \mu \mathrm{m}-$ for $5-6 ; 40 \mu \mathrm{m}$ for 7
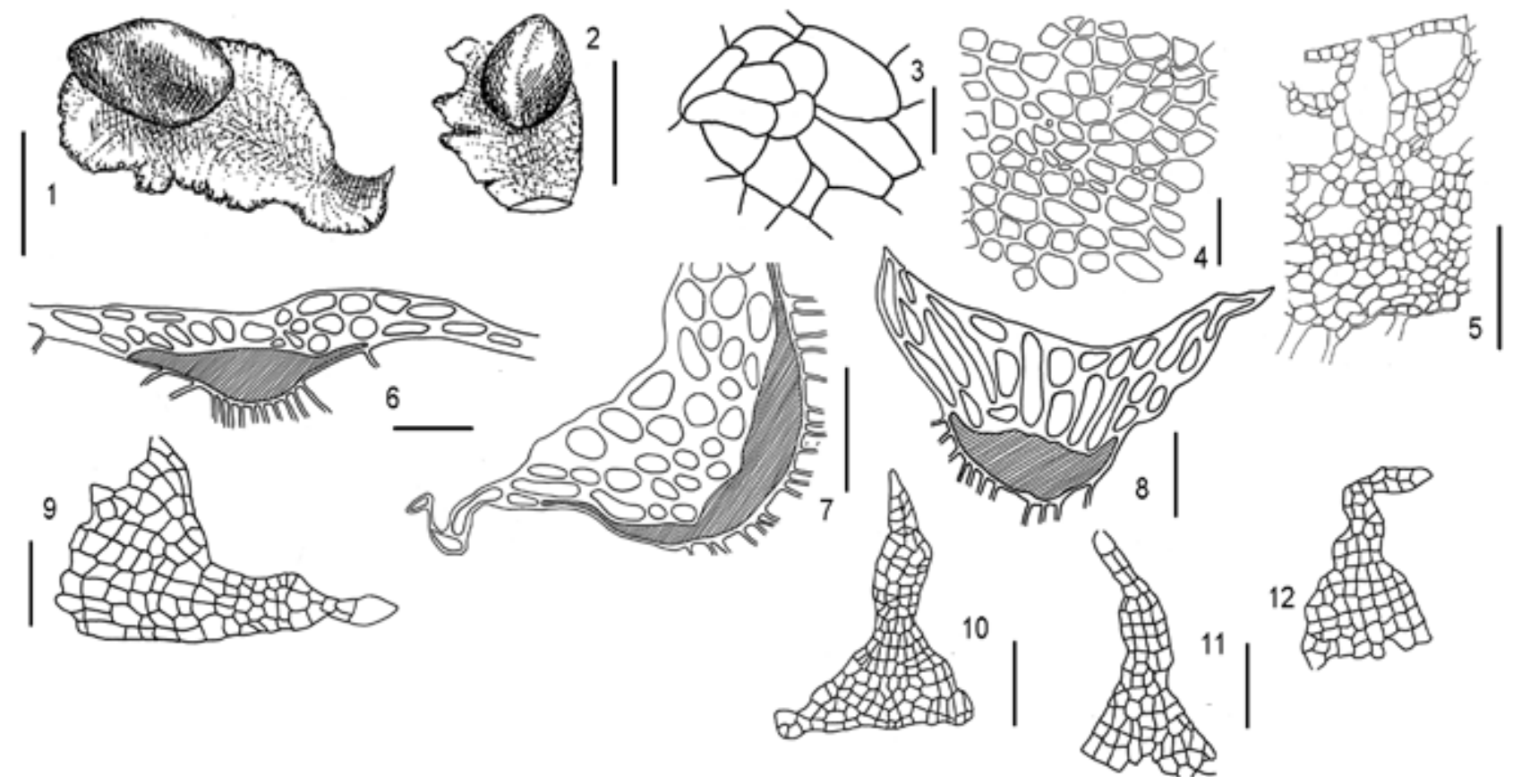

12

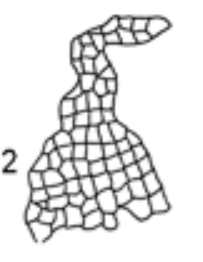

Figure 4 Clevea nana (Shimizu \& S. Hatt.) Borovichev \& Bakalin 1, 2 - thallus, dorsal view; 3 - air pores of thallus dorsal epidermis; 4 dorsal epidermis of thallus; 5-8 - transverse section of thallus; $9-12$ - ventral scales of thallus. Scale bars: $2 \mathrm{~mm}-$ for $2 ; 1.5 \mathrm{~mm}-$ for 1 ; $150 \mu \mathrm{m}-$ for $5,9-12 ; 100 \mu \mathrm{m}-$ for $3,6-8 ; 50 \mu \mathrm{m}-$ for 4 
and absent in the wings, oil-cells lacking. Aerenchima well developed, air-chambers wide and rounded, 2-3-layered near the apex and at the margin, 1-2-layered in the middle (where air-chambers narrower then higher). Lower surface greenish to rose; midrib shallow, relatively ill-defined. Rhizoids hyaline to whitish, forming cluster along midrib region. Ventral scales purplish hyaline or rose to blackish purple, in 2-3 irregular longitudinal rows or scattered thought ventral surface, ovate to lanceolate, $300-700 \mu \mathrm{m}$ long, cells delicate, large, subquadrate, 25-40(-45) $\mu \mathrm{m}$, appendage by one per ventral scale, narrowly long-acute to acuminate, always colored; oil cells absent; marginal one-celled slime-papillae rare. Sexual condition autoicous. Androecia in antheridial ostioles on a separate terminal branch of the same plant; ostioles conical, hyaline to purplish, conspicuous, androecial scales lacking. Gynoecia dorsal, 1-2 per thallus; female receptacle stalk often apparently sessile, pale purple and hyaline, 0.7-1.2 mm long, apical stalk scales present, lanceolate to linear, slime papillae not defined; carpocephalum greenish and hyaline, cupshaped, with 1-3 lobes pointing upwards, rarely horizontal. Capsule globose, dark brown, dehiscing to 4-6 irregular valves, wall unistratose, cells with annular and semi-annular bands. Seta short, bulbous, Spores brown to dull brown, $40-55(-60) \mu \mathrm{m}$ in diameter, densely warty, warts $8-10 \mathrm{ac}-$ ross diameter. Elaters brownish yellow to brown, 110-200 $\mu \mathrm{m}$ long, 8-10 $\mu \mathrm{m}$ wide at middle.

Ecology: The species grows on humus and soil covering calcareous cliffs, as well as on slopes to stream and fine-grained soil in snow-bed communities in tundra.

Distribution of Clevea nana is poorly known, currently it is reliably known for Chukotsky Autonomous District

\section{LITERATURE CITED}

Bakalin, V. A. 2010. The distribution of Bryophytes in the Russian Far East. Part I. Hepatics. Publishing Company of Far-Eastern University, Vladivostok, $175 \mathrm{pp}$.

Borovichev, E. A., N. A. Konstantinova \& E. N. Andrejeva 2012. The genus Sauteria Nees (Cleveaceae, Marschantiophyta) in Russia. Arctoa 20:181-188.

Damsholt, K. 2002. Illustrated Flora of Nordic Liverworts and Hornworts. Nordic Bryological Society, Lund, 840 pp.

Hattori, S. \& D. Shimizu 1955. Marchantiales of Japan. IV. Journal of the Hattori Botanical Laboratory 14:91-108.

Konstantinova, N. A. \& A. N. Savchenko 2012. Contribution to the hepatic flora of the Nordaustlandet (Svalbard). I. Hepatics of the north coast of Murchison Fjorden. Polish Botanical Journal 57(1):181-195.

Konstantinova, N. A., V. A. Bakalin, E. N. Andrejeva, A. G. Bezgodov, E. A. Borovichev, M. V. Dulin \& Y. S. Mamontov 2009. Check-list of liverworts (Marchantiophyta) of Russia. Arctoa 18:1-63.

Perold, S. M. 2003. Cleveaceae-Marchantiales. Sauteria nyikaensis, a new liverwort species from Malawi. Bothalia 33(2):165-171.

Rubasinghe, S. C. K. 2011. Phylogeny and taxonomy of the complex thal- and Primorsky Territory within the Russian Far East. Outside that area it is know from Zabaikal'sky Territory, Japan, China and Mongolia (see specimens examined list).

Specimens examined: RUSSIA, ZabaIKal'SKY Territory, Chita Sity Area 26.IX.1909, P. Mihno (KPABG as Clevea); CHuкотsкy Autonomous District, Wrangel Isl., Somnitel'naya Bay 23.VII.1985, Afonina (KPABG, VBGI as Athalamia byalina), 10.VIII.1985, Afonina (LE as Athalamia byalina); PrIMORSKY 'Territory, Lazovsky District, Solnechnaya Pad' stream valley 20.IX.2012, Bakalin (VBGI); Nakhodka City Area, Sestra Mountain 14.VIII.2008, Bakalin (VBGI); 17.X.2008, Bakalin (VBGI); Khasansky District, Kedrovaya Pad' State Reserve, Kedrovka River 17.V.2007, Bakalin (VBGI); Partizansky District, Lozovyi Settlement 15.IX.1974, L. V. Bardunov (VBGI); JAPAN, Saitama County, Chichibu Mts. 3.IX.1953, D. Shimizu (IRK, isotype of Athalamia glauco-virens Shimizu \& S. Hatt. f. subsessilis Shimizu \& S. Hatt. from Hepaticae Japonicae Exsiccatae \#253; NICH, holotype of Athalamia glauco-virens Shimizu \& S. Hatt. f. subsessilis Shimizu \& S. Hatt. \#52755); ibid., 31.VIII.1953, D. Shimizu (NICH, isotype of Athalamia nana \#52773; \#\#52765, 55678); CHINA, InNer Mongolia Province, Great Khingan Range, A Xi Ha Tu Geological Park 6.VIII.2010, Bakalin (VBGI); MONGOLIA, Zavhan, Numreg-gol 8.VIII.1991, R.V. Kamelin (KPABG).

\section{ACKNOWLEDGEMENTS}

The figures were kindly prepared by Mr. M. A. Bakalin, to whom authors are sincerely grateful. Authors are grateful to Dr. N. A. Konstantinova for the help in preparation of the present account, as well as to anonymous reviewers for valuable comments. We are greatly indebted to the curators of LE (A. Potemkin) and NICH (M. Mitzutani) as well as Dr. E. Andrejeva for specimen loans. The work was partially supported by RFBR (grants no. 12-04-91150, 1204-01476, 12-04-90804, 13-04-00775).

loid liverwort family Cleveaceae Cavers. Thesis (PhD), University of Edinburgh, Edinburgh, 264 pp. http://www.era.lib.ed.ac.uk/ bitstream/1842/5298/1/Rubasinghe2011.pdf

Rubasinghe, S. C. K., D. G. Long \& R. Milne 2011a. A new combination and three new synonyms in the genus Clevea Lindb. (Marchantiopsida, Cleveaceae). Journal of Bryology 33(2):168-169.

Rubasinghe, S. C. K., R. Milne, L. L. Forrest \& D. G. Long 2011 b. Realignment of the Genera of Cleveaceae (Marchantiopsida, Marchantiidae ). The Bryologist 114:116-127.

Schlyakov, R. N. 1982. The Hepatics of the North of the USSR. Vol. 5. Leningrad, Nauka, 196 pp. (in Russian) ШАяков P.Н. 1982. Печеночные мхи Севера СССР. АенинграА: Наука, Т. 5. 196 c.].

Schuster, R. M. 1992. The Hepaticae and Anthocerotae of North America East of the Hundredth Meridian. Vol. 6. Columbia University Press, Chicago, 937 pp.

Shimizu, D. \& S. Hattori 1954. Marchantiales of Japan. III. The Journal of the Hattori Botanical Laboratory 12:53-75.

Singh, S.K. \& D.K. Singh 2009. Hepaticae and Anthocerotae of Great Himalayan National Park (HP), India. Botanical Survey of India, Kolkata, 465 pp. 